\title{
Dead Men's Fingers
}

\section{One of the Most Interesting Groups of Our Less Common Fungous Growths

\author{
By Dr. William Alphonso Murrill, New York Botanical Garden
}

NE of the summer boarders insisted that it was sewer pipes as explanation. The mycologist of the party investigated beneath the house and soon emerged triumphant bearing aloft a magnificent specimen of the veiled stinkhorn. After he had explained how the green, slimy cap, borne on the white stem, was attractive to flies because of its odor, which developed only after the spores were mature and ready for distribution, all became interested; and it was one lady's opinion that the odor, like that of the skunk, was "strong but not particularly disagreeable." From time immemorial, man has dreaded the unknown and greatly exaggerated what he has not understood!

The stinkhorns, or "dead men's fingers," as they are sometimes called, occur during the summer and fall about buildings, in cultivated grounds, or on the ground in woods; and most of them make their presence known by a powerful fetid odor. The underground mycelium, or spawn, consists of cord-like strands matted together, to which are attached rounded, pink or white "eggs," and from these arise at the proper season conspicuous stalks bearing at their apex the spores and the malodorous slime so attractive to blow-flies, green-flies, carrion-beetles, etc.

If one of these "eggs" is cut open, all the parts of the mature fruit-body may be seen in embryo compactly duplicata. The cap is bell-shaped, 5 centimeters long, the surface appearing strongly reticulate-pitted after the fetid, olivaceous gleba has been devoured by flies or washed away by rains; apex truncate, perforate; spores oblong-ellipsoid involved in mucus at maturity; stem fusiform-cylindric, tapering at each end, cellularspongy, white, hollow, 10-20 centimeters high, 2.5-3 centimeters thick; veil white, reticulate, var centimeters thick; veil white, reticulate, variable in fragth, sometimes much expanded, always conspicuous, fragile; egg globose, nearly

5-7 centimeters in diameter.
This very conspicuous and objectionable species occurs in the United States about buildings and near stumps in fields and in the edges of woods. It may be easily recognized by its conspicuous veil, which is attached near the apex beneath the cap and hangs down to the middle of the stem or lower. There are few finer examples of natural lace-work than this delicate white veil. The mature fruiting surface, or gleba, is extremely fetid, proving attractive to flies, which disseminate the spores. The stinkhorns have usually been considered poisonous, although little experimenting has been done in the group on account of their odor. According to McIlvaine, the eggs are tender and excellent for food when cut in slices and fried or stewer. I have found the veiled stinkhorm frequently the veiled stinkhorn frequently is smooth instead of coarsely pitted; and its odor is: less penetrating and disagreeable. The veil is a very thin, delicate membrane, which is usually concealer lieneath the cap and therefore not noticed.

I have specimens from Canada and most of the eastern states and have found them at times in great abundance. One autumn at Ithaca I discovered a bed in an old sawdust pile from which I brought in eggs: and mature plants by the basketful. At a certain and mature plants by the basketful. At a certain ibtain photographs that were not blurred by the movement of the stalks.

The common stinkhorn of Europe, Ithyphallus impudicus, looks very much like the sawdust stinkhorn, but has no veil of any kind and its cap is coarsely reticulate like that of the veiled stinkhorn. A pink variety is said to occur in the southern United States, lut I have seen no typical specimens except in Europe, where it is fully as abundant and offensive as is our veiled stinkhorn in the eastern United States. A gentleman in France freed his grove of this species by removing the soil for a foot or more at every spot where the fungus occurred and filling the cavities with quick-lime. This method should be applicable about houses and on lawns for any species of the group. A destructive root-rot of the grape is attributed to the common stinkhorn in some parts of Europe.

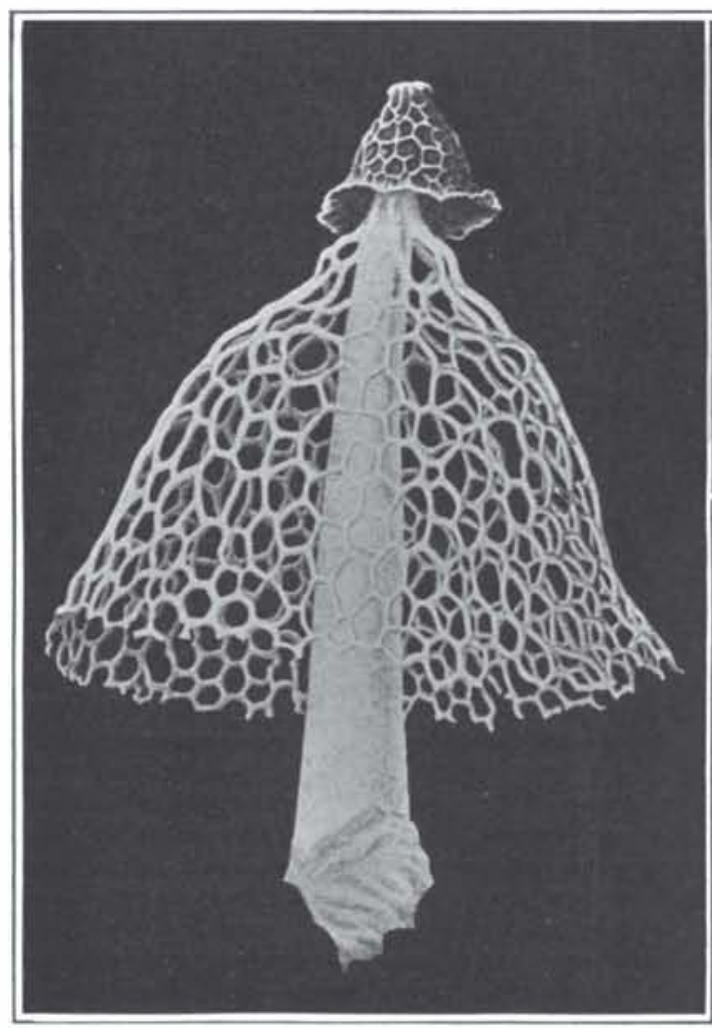

tucked away in its various layers. Between the thin inner and outer coats is a thick gelatinous layer, which is traversed by a central column surrounded by a dark green substance. If a fully grown "egg" is kept warm and moist, it will soon develop, and the various stages may be watched. The central column is composed at this early stage of cells closely compressed together, this early stage of cells closely compressed together,
which absorb water and expand very rapidly, breaking through the roof of the "egg" and leaving its "shell" as a cup, or volva, at the base of the elongated stalk This expansion usually takes place at night and is so very rapid that the movement actually becomes visible. The dark green mass, borne aloft on the stalk, melts to a slimy fluid containing minute, ellipsoidal spores; while a fetid odor is generated and borne on the breezes to all the flies in the neighborhood, advertising the fact that a banquet is prepared for them in exchange for their assistance in distributing the spores. The stinkhorns, or phalloids, are remarkable for their peculiar and interesting forms, their attractive coloring, and their fugitive occurrence. About one hundred species are recognized, widely distributed throughout temperate and tropical regions, but many are imperfectly known. Of the commoner American are imperfectly known. Of the commoner American species that are provided with conspicuous stalks and
possess the well-known disagreeable odor, perhaps the commonest is the veiled stinkhorn, or Dictyophora

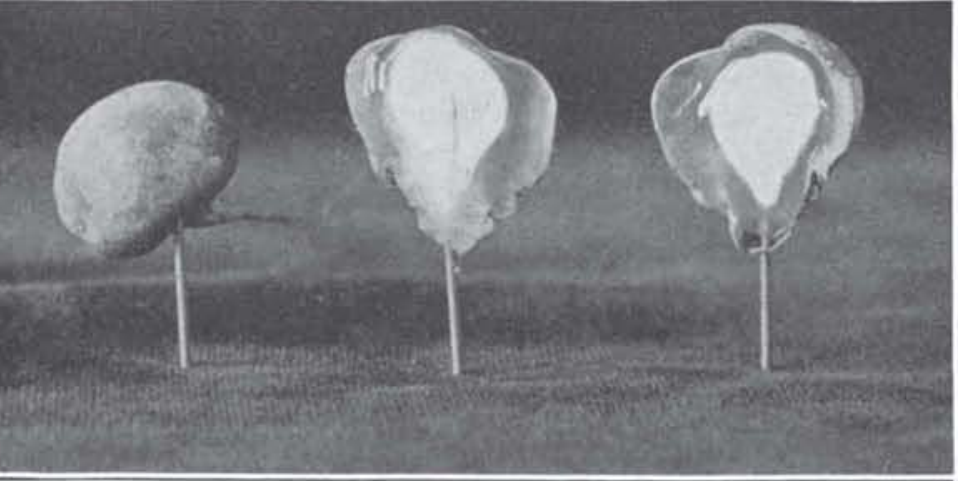

Left: A handsome specimen of Dictyophora indusiata, from Brazil, a species that displays a veil of unusual proportions. Center: Eggs of the ordinary veiled stinkhorn of the United States which, when cut open, show the mature fruit-body in perfect miniature. Right: The branched stinkhorn, Lysurus Borealis, of New York. This is a comparatively recent member of the metropolitan flora, having first been
noted by the author in 1911

Some strange forms of the stinkhorn fungi

ward to North Carolina and Tennessee. Fully grown eggs when brought into the house will usually develop mature plants in a single night.

In the tropics, I have collected a species with a much larger veil called Dictyophora indusiata, which is one of the most remarkable and beautiful natural objects I have ever seen. Specimens have been sent to me from. Brazil, Colombia and the Philippines. This species is white, but there is another in the tropics and in the southern United States which is red all over and has no veil. In Hawaii the red species attack the roots of sugarcane, causing an average loss of about ten per cent of the crop. Its development from the egg has been carefully traced, showing that in the later stages the stalk elongates as much as an inch and a half in a single minute:

In the sawdust stinkhorn, Dictyophora Ravenelii, the cap is conic-bell-shaped, 2.5-3.5 centimeters long, the surface white and granulate or minutely wrinkled after the disappearance of the olivaceous gleba; apex smooth, white, umbilicate, closed by a thin membrane or at length perforate; spores oblong-ellipsoid, involved in mucus ; stem cylindric, slender, tapering at each end, cellular-spongy, white, hollow, 10-12 centimeters high, 2 centimeters thick; veil membranous, usually scarcely half the length of the cap and concealed beneath it, very rarely protruding; egg ovoid, pinkish, 4-5 centimeters in diameter, containing the lower half of the veil attached about the base of the stem.

This species occurs in abundance in old sawdust piles and about rotting $\operatorname{logs}$ and stumps in woods and fields in the eastern United States and Canada. It may be readily distinguished from the veiled stinkhorn by the absence of a conspicuous, reticulate veil; its cap

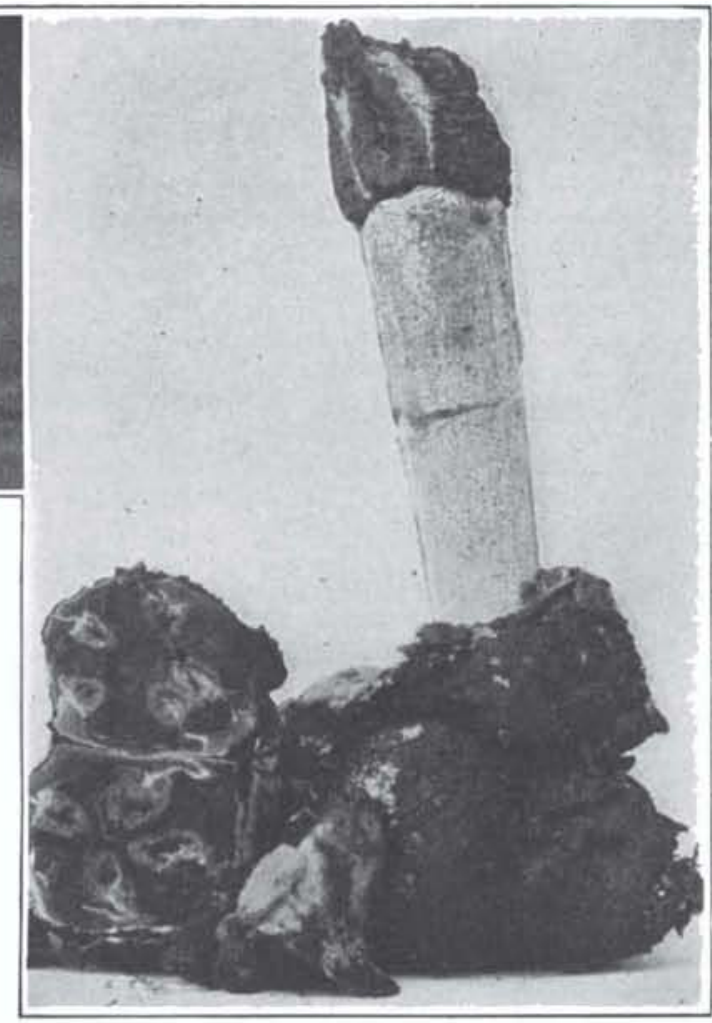

The elegant stinkhorn, Mutinus elegans, has a stem horn-shaped, cylindric, tapering gradually to the apex, pitted, hollow, white or pinkish below, bright-red olorange above, 10-17 centimeters long, about 2 centimeters thick; apex conic-acuminate, perforate; gleba greenish-brown, semi-fluid, fetid, smeared over the upyer portion of the stem in an indefinite manner; spores: oblong-ellipsoid ; veil none; egg oblong-ovoid, pinkish, 2.5-3 centimeters long.

This species is very conspicuous by reason of its size and brilliant red or orange color. Its odor is sickening and penetrating, but not so strong as that of the veiled stinkhorn. It occurs quite commonly in the United States in woods or in cultivated ground rich in decayed vegetable matter. I have specimens from most of the eastern states and have collected it at several places in New York, Pennsylvania, Virginia, and 'Tennessee, usually in woods or near trees. At Ohio Pyle, Pennsylvania, I found it abundant about an old stump beneath a porch, where the fruit-bodies appeared daily for some time. Excellent specimens were also cbtained from a tub in one of the greenhouses at the New York Botanical Garden. The eggs are curious wbjects, especially in section. According to McIlvaine, they are edible when sliced and fried.

Another American species, Mutinus Raveneli.i, is (Continued on page 10\%) 
LEGAL NOTICES

\section{PATENTS}

IF YOU IIAVE AN INVENTION 1 which you wish to patent you can write fully and freely to Munn \&
Co. for advice in regard to the best way of obtaining protection. Please send s'ietches or a model of your invention and a description of the device, explaining its operation. All communications are strictly con-
fidential. Our vast practice, extending over a period of seventy years, enables us in many cases to advise in regard to patentability without
any expense to the client. Our Handany expense to the client. Our HandBook on Patents is sent free on re-
quest. This explains our methods, terms, ete., in regard to Patents, Trade Marks, Foreign Patents, etc. SCIENTIFIC AMERICAN

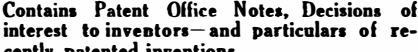

MUNN \& CO., sompiriters Woolworth Building.
Tower Building. NEW YORK Scientific American Building, WASHINGTON, D.C.
Hobart Buildiag, SAN FRANCISCO, CAL. CAICAGO,

Annual Subscription Rates Scientific American Publications Scientific American (established 1845) one

Scientific A.......... Monthily (estabiished $\$ 6.00$ Postage prepaid in United states and posse
sions, Mexico, Cuba and Panama. Foreign Postage
Scientificic American \$1.50 per year additional.
Scientific American \$1lonthly $72 \mathrm{cc}$ per year ad ditional.

Scientific American 75c por vear additional.
Scientific American Monthly 36c per year additional.
The combined subscription rates and rates to
foreign countries including Canada, will be

Remit by postal or express money order, bank
draft or check.

Classified Advertisements

No less than five nor more than 12 lin acepted. Count seeven words to the line. Al
orders must be accompanied by a remittance. AGENTS WANTED

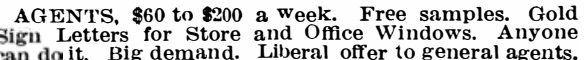
can do it. Big demand. Liberal offer to general agents.
Metallic Letter Co., 431X N. Clark St., Chic ago. BUSINESS OPPORTUNITY WoU LD like to get in touch with Aeroplane Manu
acturers or others who might become interested ant experiments. Guaranteed to be both interesting and
practical.
Address E. M. Blacksher, P.O. Box 338, BUSINESS OPPORTUNITY

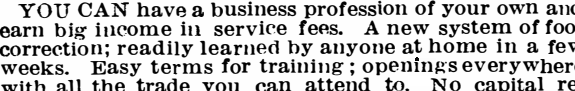
weeks. Easy terms or training; openings everywhere
with all the trade you can attend to. No capital re
quired or goods to buy, no agency or soliciting. Addres BUSINESS OPPORTUNITY

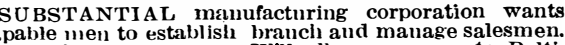

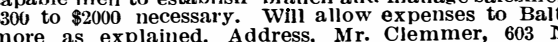
nore as explained. Address, Mr.
Entuw St.. Baltimore. Md.

FOREIGN STAMPS

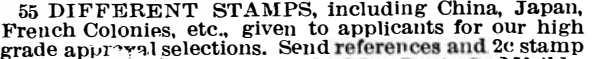

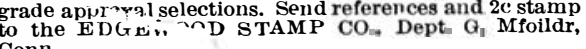

\section{WANTED}

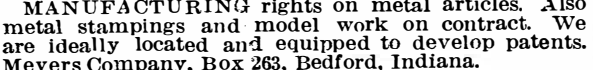

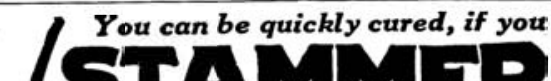

STAMMER

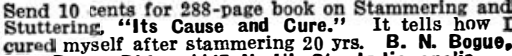

cured myself after stammering 20 .rsi
B. N. Bogue.
Zy34 Bogue Bldg., 1147 N. 1II. St., indiananolis.

\section{South Dakota}

\section{State School of Mines}

Rapid City, South Dakota

Has just closed the best year in its history. Few institu-
tions have at their doorway such a wonderful outdoo

laboratory as the Black Hills region.

Degrees are granted in Civil,
and Metallurgical Engineering.

Expenses are low and much attention is given the in dividual studeut. W $\mathrm{w}$. views address, The President.
Dead Men's Fingers

(Continued from paye 9 f $_{4}$ quite similar to the elegant stinkhorn in con ward the apex, and is much rarer, occuring in old fields in clay soil practically destitute of leaf-mold or in grassy ground partly shaded.

The only European species of this genus, Mutinus caninus, has a slender, cylindric stem which tapers in neither direction, and a small cap that is set off rather charp the respect quite decidedly from the elegint stinkhorn, although resembling it in color and general form. It has been reported $a$ few times from the United States, but 1 have seen no American specimens. It somld give me much pleasure to receive and the stem sometimes varies to white. All the species of Mutinus readily lose the greenish slime containing the spores the greenish slime containing the spores
since it is eagerly devoured by flies and since it is eagerly devoured by flie
easily washed away by light rains.

The branched stinkhorn, Lysurus borealis, grows solitary or clustered, 10-12 centimeters high; stem white, divided above usually into six but sometimes five or seven, narrowly lanceolate hollow arms, which are incurved above, with pale flesh. colored backs traversed their entire length by a shallow furrow ; cavity of the stem nearly closed at the base of the arms by a diaphragm through which there is an opening upward into a closed supported on the dome and closely embraced by the arms; spores oblong, white; eggs clustered, 3.5-4 centimeters in diam. eter.

The odor of the mature plant is very vile and penetrating at close range, somewhat resembling that of fresh guano, but it is not pervading like that of the veiled "faint" quality of most stinkhorns. The slime containing the odor is inside the fire rays and oozes through the spaces between them as they spread slightly. The "eggs" are in clusters of three or four or more, and are about 3.5-4 centimeters in diameter. A section of an "egg" shows the conspicuous cap enclosed by the thin, white inner wall, while the stem is much compressed until the elongation hegins which pushes the cap rapidly into the air According to Mr. C. G. Lloyd, whose publications on this group have furnisher some of the illustrations here used, the branched stinkhorn may have been introduced from Australia or Sonth America, where species occur that greatly resemble it. Both in Europe and in the United States it seems to have appeared other cultivated places. Dr. Peck found it in an asparagus bed, while it was colit in an asparagus bed, while it was collected last October at the New York Botanical Garden in a gladiolus bed. Several collections have been made in Maspotato fields, and one in a lawn newly plowed and seeded. Professor Beardslee found an acre of it in Ohio, where heavy sod had been turned and allowed to decay. It had not been seen there befor and its sudden appearance in such p
fusion was rather difficult to explain.

The Last Word in Power Houses (Continued from page 98)

and into the main channel of the river before any of it reaches the intake again. The coal unloading tower also has points of interest. Here, also, the engineers faced the necessity of reducing weight in order to permit the use of concrete. A great deal of height and weigh was eliminated in this instance by using an incline and which carries the coal up ers within the plant. The fuel is lifted from the barges by means of a crane hoist of standard design and dropped into magnetic separator. From there it passes into the crusher and thence to the belt. In all large generating stations, the lectric currents and voltages are of such magnitude, and the necessity of centralzed control is so imperative it would be hand. For these reasons they are equipped with electric motors which open and close them and which are all con trolled from a central control switchboard ocated in the operating room.

The pipe room, referred to above as a pecial feature of the electrical equipment, gets its name from the fact that it uits through which the wires from the entral control switchboard are led out to the small motors on the high voltage witches. Through other pipes terminat$\mathrm{ng}$ in this room also pass the wires leadng to the instruments which mounted on an instrument board located in the central operating room directly in back of the control switch board, and his machines are producing and to what ubstations the energy is being transmit-

The layman hearing this room described and seeing it is surprised that no one ever thought of it before. In
the idea is simplicity itself.

In plants where no such room is proided the pipes are terminated in a trough epressed in the floor of the operating room in back of the switch boards. This in the trough, which increases the difficulty of tracing faults in the wiring and in the event of one wire burning out, the fire may easily be transmitted to the in controlling other circuits, resulting restoring it, all of which is fatal to the interests of the power company.

The Philadelphia Electric Company while studying ways and means of eliminating these delays and fire risks an thus assuring the company's ideal of continuous service, has substituted its pipe boards.

The pipes are arranged to come up out of the floor of the pipe room directly under the respective switchboard pane ply. The wires of each circuit are separated from those of other circuits throughout so that a fault developing in the con mitted to that of any other circuit convenience in tracing defects in the wir ng and in testing switch board instruments, each wire passes through a fuse or cut-out block mounted on a termina
board in the pipe room and labeled so that the electrician can identify each wire without delay.

It is altogether probable that this system of arranging control wiring will be come standard for large power house the country. It was first inpany in its Chester Station which tran mits electrical energy to Philadelphia at 66,000 volts pressure over an aerial line on steel towers. This plant was completed in 1918, in which year it was considered the last word in the production of electricity. It is equipped with two of the same size and type turbo-generators as those being installed in the Delaware Station.

As indicated, however, there have been several new developments in this station not to be found in any other power plants. The boilers are of the same type and But in order to provide for the possible installation of oil-burning equipment if that should become necessary later, the boilers have been set higher than in normal practice when stokers are used, the tubes being fully twelve feet from the grates. This has resulted in an increase of efficiency in the combustion of gases particularly notable in coal containing a

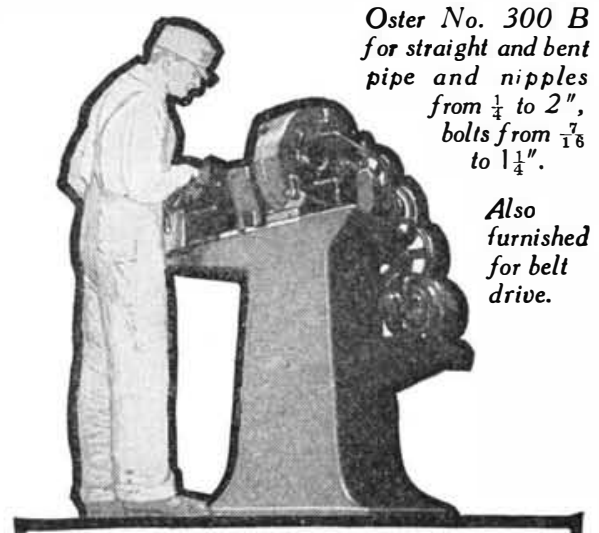

Speedier Pipe-Threading

$\mathrm{I}_{\text {count on from this machine: }}^{\text {ERE'S the production you can }}$

53 seconds to thread

2 -in. pipe on slow speed

20 seconds to thread

1 -in. pipe on fast speed

$13 / 4$ minutes to cut off

2 -in. pipe on fast speed

$1 \frac{1}{2}$ minutes to cut off

1 -in. pipe on fast speed

9 seconds to cut of

$1 / 4$-in. pipe on fast speed

For prices and full details, write

The

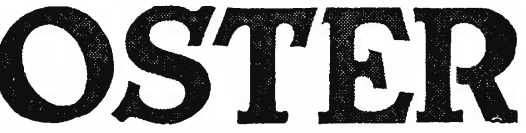

Manufacturing Company

East 61 st Place, Cleveland, O.,U.S.A.

GPACHINES Corliss Engines, Brewers The VILTER MFG. CO.
989 Clinton Street

GAS, AIR, WATER, GASOLINE PUMPING LEIMAN BROS. AIR PUMPS

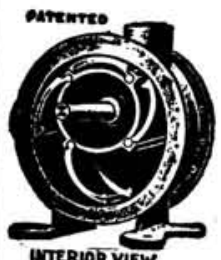
ROTARY-POSITIVE

LEIMAN BROS. 81 WALKER ST., N. Y.

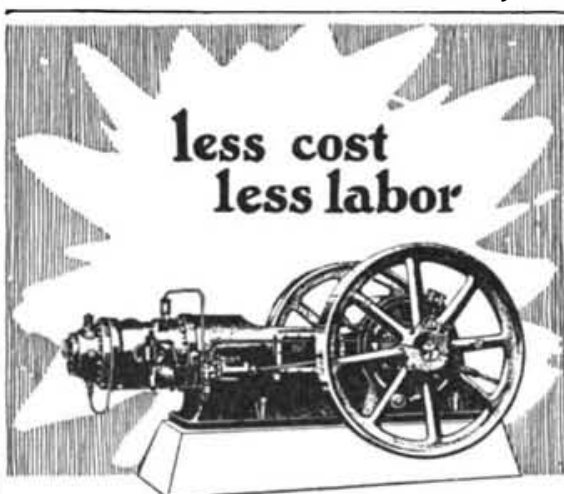

$T_{\text {world }}^{\text {HE distribution of Bessemer Oil Engines is }}$ world wide. No other power equipment
combines so many advantageous features. Less floor space needed, compactness and sim-
plicity of design. No skilled labor required for its operation. These economies plus the low cost of operating on any grade of fuel oil make the Bes-

THE BESSEMER GAS ENGINE CO.

14 York Street, Grove City, Pa.

BESSEMER OIL ENGINES 


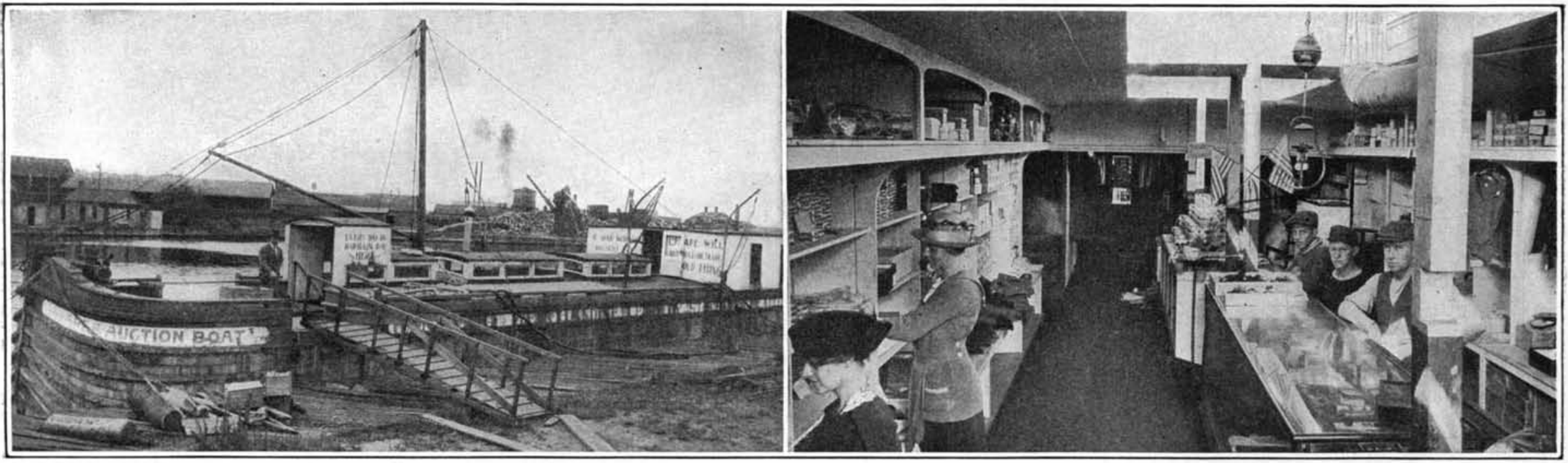

Two views of a travelling and floating store which stops at various towns and villages along the St. Lawrence River

Moving Houses to Clear the Mines

H IBBING, Minnesota, called "the richest village in H the world," is going through a novel experience. A part of this prosperous town in the iron range is being moved. Hibbing is one of the new towns which have sprung up since ore was discovered, and it is really s sort of "industrial romance" made practical. It is not literally a fact that the whole of Hibbing is being moved, but people talk that way. Sixteen blocks of the original part of Hibbing, overlay a valuable " 40 " of land which it is desired to exploit; and as this town has never failed to grasp opportunities, this one-third of the village is being cleared of buildings so that mining companies can have access to the valuable deposits. In place of this cleared away section, a new part of the village will be reared on the outskirts.

Because of the number and the size of some of the buildings to be moved, this activity has called for the highest skill on the part of the home movers. Steam locomotive tractors, equipped with traction belts, have lieen largely used, together with the usual jacks and heavy trucks, logs, etc., as shown in our cover illustration.

It is almost impossible to estimate the many millions which will be needed to tear down and rebuild such a large area, but Hibbing feels it is making history; and so all classes of labor, the mining companies and citizens, are working side by side to accomplish results. It seems an almost superhuman achievement, but in the end another city will rise as the result of a new kind of town building and the exercise of a community spirit which is working for the good of all. In a short time there will be one continuous Hibbing entirely different from the original village, but a witness of the heroic work done in the iron ranges.

As a matter of fact, the ringes, on one of which Hibbing is located, furnish three-fifths of the millions of tons of ore which the United States contributes to the world. All this is a part of the development of the past fifty years, and the army of employees necessary to work this ore is a vast one. It is estimated there are 125,000 men working on these ranges in Minnesota alone, and the industry creates a certain atmosphere and makes town, railroads and immense lake traffic. The number and nationalities of foreigners employed is a revelation to one who visits the ranges for the first time. Perhaps no activity in this country can furnish such a diversity of nationalities. Canadians, English, Scotch, Hollanders, Bulgarians, Montenegrins, French, Norwegians, Belgians, Germans, Swiss, Finns, Russians, Swedes, Danes and others are found in various occupations. Many have gone directly to the mines on anding in this country Others have lived in the United States for a number of years. Skilled and unskilled, they are important factors in the development of the range. First came the Scandinavians, Finns and Austrians to help dig Lake Superior ore, and following some time later were the races of Southern Europefrom Serbia, Montenegro, Bulgaria and Croatia.

These workers are young or middle aged, and their children attend schools which are up-to-date and of standing far ahead of those of the countries from whence these people came. Hibbing recently erected grade building at an expense of one hundred and twenty-five thousand dollars. The range towns are interested in all outside mitters. They have a free, genercus spirit-a solt of "spirit of the range," which comes from familiarity with colossal movements that are taking place daily. Great ore pits, heavy cars loaded with rapidity and speed, the latest improvements in michinery-these are features of this stupendous business. Nowhere else in the world is it possible to uncover a bed of ore which stretches for mile after mile, and to mine it in places as if it were sand by means of steam shovels, ocomotives and trains of cars.

An interesting feature in connection with the ore mines of Minnesota is that many of them are owned by the State; in fact, every year the permanent school, university and trust funds receive from this source by way of royalties about seven million dollars.
Business As Usual Aboard Ship

W HETHER it is to escape high rents and high the fact remains that business has followed in those footsteps of many families which lead to the houseboat. In many different parts of the country we find all kinds of business being done aboard ship and apparently with excellent results.

In the heart of New York City, for instance, there are some nine houseboats one and two stories in height, moored to a dock in the shadow of one of the huge East River bridges. These houseboats serve as the quarters for as many fish and seafood dealers, whose wares come direct to their backdoor when the fishermen pull up every day. In the outskirts of New York City there is a hardware and ship chandler establishment which thrives far out in the bay, aboard a houseboat. There are many refreshment stands and other similar establishments which find it the part of good business to operate aboard ship rather than on good old terra firma.

Most unique, perhaps, is the travelling store idea, of which the accompanying illustrations convey an excellent pictorial description. This particular establishment has travelled over the St. Lawrence River for several years, and it is said that wherever it stops, the trade is sure to be flourishing. Not only do the inhabiamong the offerings of this travelling store, but they also take this opportunity of stocking up on numerous articles of food, wearing apparel, household utensils, and so on. The line of goods carried in this floating store ranges from a feather for Milady's hat, to canned cherries for dessert, most of the stock having been bought at auction or at receiver's sales in order to reduce the selling prices. Residents of the rural disrich recill the peripatetic peddler, who came through the country-side at intervals with his miniature department store on his horse-drawn cart. Where water transportation is good, why not have the water-borne peddler?

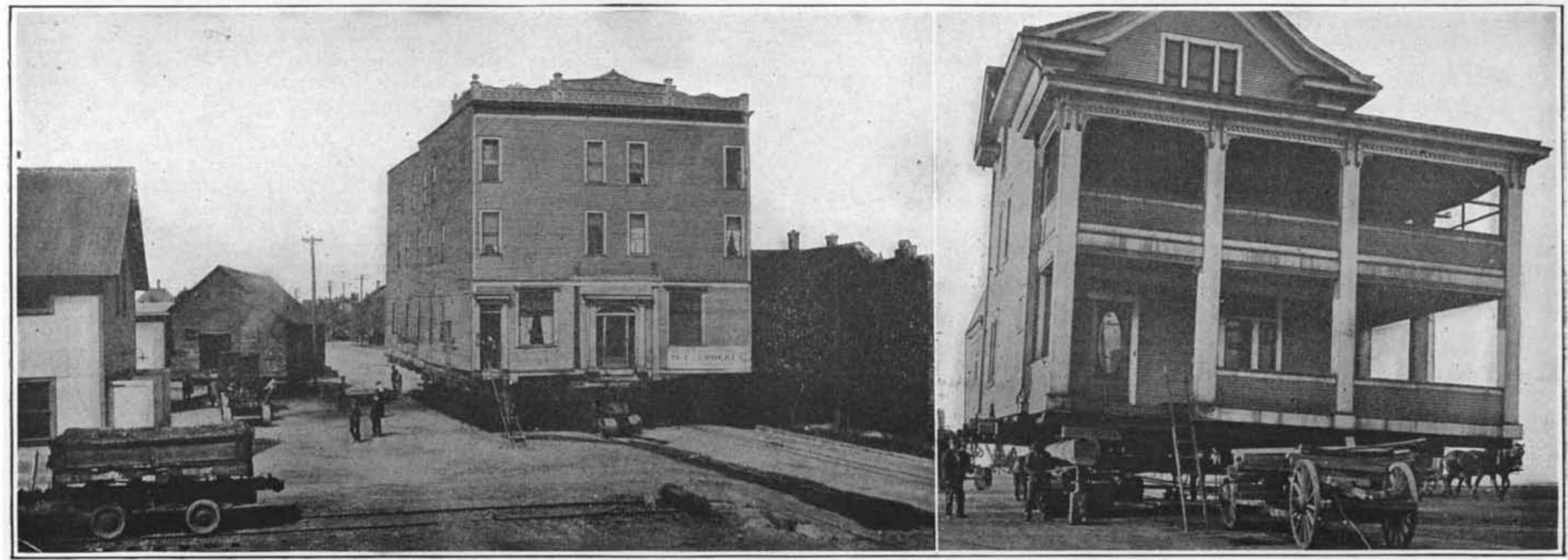

Left: Colonia Hotel being moved to South Hibbing. Note barn at left which is being hauled around the hotel building. Right: One of the numerous residences being moved to South Hibbing, in order to clear valuable mine lands

Two views which, in conjunction with the cover illustration, furnish an excellent idea of Hibbing's house-moving activities 